\title{
Explaining unemployment trends in the Netherlands is
}

\author{
Robert A.J. Dur \\ Erasmus University Rotterdam, Tinbergen Institute, P.O. Box 1738, 3000 DR, Rotterdam, \\ The Netherlands
}

Received 1 January 1998; accepted 1 October 1999

\begin{abstract}
In this paper, a small macroeconomic model of the Dutch labour market is estimated. The model is used to detect the causes of the rise in unemployment since the early $70 \mathrm{~s}$. In contrast to existing empirical work, we treat labour supply as an endogenous variable. This adjustment appears to have serious consequences for the conclusions drawn. In particular, we show that the detrimental effect of the replacement rate on unemployment has been overestimated in earlier studies. Furthermore, we include contractual working time in the analysis. Our estimates imply that work sharing does reduce unemployment, but at a high cost. Because hourly wages rise in response to reduced working hours, aggregate output is damaged quite strongly. C 2001 Society for Policy Modeling. Published by Elsevier Science Inc.
\end{abstract}

Keywords: Unemployment; Labour market — the Netherlands; Wage formation; Labour supply; Working time

\section{Introduction}

Persistently high unemployment has been one of the major problems in most OECD countries since the end of the seventies. Economists have put much effort on trying to find explanations for this particularly inefficient phenomenon (see Bean, 1994, for a survey). One widely known explanation, suggested in the

is A large part of this paper was written while the author was with Research Centre for Economic Policy (OCFEB), and Utrecht University, Economisch Instituut/CIAV.

* Tel.: +31-10-4081431; fax: +31-10-4089147.

E-mail address: dur@few.eur.nl (R.A.J. Dur). 
seminal papers by Layard and Nickell $(1985,1986)$, is that several factors have tended to generate pressure for "too high" real labour costs. These factors may include the level of unemployment benefits, taxes, and the gap between consumer and producer prices. The highly influential Layard-Nickell model, which is characterized by imperfect competition on both product markets and the labour market, has been applied to many OECD countries in order to account for the unemployment path (see for example Bean, Layard, \& Nickell, 1986; Layard, Nickell, \& Jackman, 1991). In this paper, we try to explain unemployment trends in the Netherlands (1970-1994) by using the Layard-Nickell approach. We estimate a small macroeconomic model of the Dutch labour market, consisting of an employment equation, a real wage equation, and an equation for the labour force. The model is used to detect the causes of the rise in unemployment since the early $70 \mathrm{~s}$ in the Netherlands. Furthermore, the model sheds light on the usefulness of several policy options to combat unemployment.

The paper is built up as follows. In Section 2 a very brief overview of the model is presented. In Section 3, the estimation results are reported and commented on. In Section 4 we use the estimated model to account for unemployment trends in the last decades. Section 5 concludes. $^{1}$

\section{The model}

The model we use consists of three equations: an employment equation, a real wage equation, and an equation for labour supply. The equation for employment is based on a standard model of a profit-maximizing firm operating in an imperfectly competitive product market. Employment depends on the hourly real wage, contractual working hours per employee, the price elasticity of demand for the firm's product, the capital stock (which is taken as given), and technical progress. Furthermore, aggregate demand fluctuations may affect employment. Labour supply, which is defined as the number of people willing to work at the going after-tax real wage, is modelled in the standard neoclassical way. The equation for labour force participation contains the after-tax real wage, unemployment (to account for a discouraged and/or added worker effect), the size of the population, and the level of unemployment benefits. The latter variable may negatively affect labour supply of partners of unemployed workers due to an income effect. Also, if the unemployed workers' search behaviour is imperfectly monitored, unemployed workers may drop out of the labour force (no longer search for a job) if unemployment benefits are very generous. The wage equation is intended to be very general so that wages can be assumed to be determined by powerful unions, firms, a bargain between employers and unions, supply and

${ }^{1}$ A more extensive treatment of the model and a more elaborate discussion of the estimation results can be found in Dur (1996) and on the home page of the Journal of Policy Modeling: http://www.elsevier.com/locate/jpo 
demand, or a mixture of all these. Hourly real wages are affected by all variables entering the labour demand equation (except for aggregate demand fluctuations), the aggregate unemployment rate, the level of taxes and unemployment compensation, and the difference between consumer and producer prices. A number of theoretical studies suggest that hourly wages increase if contractual working time is reduced (see, e.g., Calmfors, 1985). Therefore, contractual working time is also included as an explanatory variable in the wage equation.

The model is closely related to that of Layard and Nickell $(1985,1986)$. There are three differences. First, we do not impose cross-equation restrictions on the model, which ensure that capital formation, labour force growth and technical progress are neutral with respect to unemployment. Layard and Nickell assume that any change in these highly trended variables, induces a real wage adjustment that exactly neutralizes its impact on unemployment. Recently, Madsen (1994) criticizes this assumption by arguing that these restrictions are neither consistent with Layard and Nickell's assumption of imperfect competition, nor empirically valid for about half of the OECD countries (including the Netherlands). Secondly, we treat labour supply as an endogenous variable. Most studies aimed at accounting for unemployment growth leave labour force participation unexplained (see, however, Pissarides, 1991, and Madsen, 1994). There are theoretical arguments for two-way relationships between labour market outcomes (e.g., wages and unemployment) and labour supply. Furthermore, exogenous variables entering the employment and wage equation may also impact labour supply (e.g., taxes and the replacement rate). By endogenizing labour supply, we hope to learn more about adjustment processes in the labour market and about the effects of several policy variables. Finally, we allow the number of contractual working hours per labour year to affect unemployment. Earlier studies in the same spirit neglected possible effects of work sharing on unemployment (including all studies focusing on the Netherlands). Contractual working time has been reduced with some $20 \%$ from the beginning of the 70 s until mid 80 s in the Netherlands. Hence, even if the effect of reduced working hours on unemployment is small, it might have had a significant effect on unemployment during the last decades. Furthermore, it is important to shed some light on its effect on unemployment in the light of the recent pleadings by unions for a shorter working week.

\section{Estimation results}

The equations for employment, real hourly wages, and labour supply have been estimated using annual data over the period 1969-1994 by iterative three-stage least squares. The sources of the data used, including a detailed description, can be found in Dur (1996). The estimation results are presented in Table 1.

I find a long-run real wage elasticity of labour demand of -0.54 , which is comparable to earlier research (see den Butter, 1993, for a review). The 
Table 1

Estimation results

\begin{tabular}{llll}
\hline & $\begin{array}{l}\text { Employment } \\
\text { (total hours worked) }\end{array}$ & $\begin{array}{l}\text { Real hourly } \\
\text { wage }\end{array}$ & $\begin{array}{l}\text { Labour force } \\
\text { (persons) }\end{array}$ \\
\hline Capacity utilisation & $\begin{array}{l}1.08(6.49) \\
-0.54(9.79)\end{array}$ & $0.28(6.51)^{\mathrm{a}}$ \\
$\begin{array}{l}\text { Real hourly wages } \\
\text { Capital stock }\end{array}$ & $\begin{array}{l}0.74(8.67) \\
\text { insignificant }\end{array}$ & $0.80(19.64)$ & $-0.77(8.07)$ \\
Contractual working hours & & $-1.10(5.85)$ & $-0.28(2.25)$ \\
Unemployment & & $0.21(2.43)$ & $-0.21(3.42)$ \\
Replacement rate & & $-0.92(8.49)$ & $-0.28(-)^{\mathrm{a}}$ \\
One minus direct tax wedge & & $0.58(6.05)$ & $-0.28(-)^{\mathrm{a}}$ \\
Consumer minus producer prices & & & $1.00(-)^{\mathrm{b}}$ \\
Working-age population & $-0.11(1.19)$ & $0.13(1.57)$ & $0.80(17.60)$ \\
1st adjustment coefficient & 0.98 & insignificant & insignificant \\
2nd adjustment coefficient & 0.59 & 0.99 & 0.99 \\
$R^{2}$ & & 0.18 & -0.20 \\
Durbin's $h$ & & & \\
\hline
\end{tabular}

$t$-Values in parenthesis, all variables in logs except for the unemployment rate.

a The explanatory variable is the real hourly consumption wage.

$\mathrm{b}$ Working-age population minus the number of people receiving disability, early retirement, or widow's benefits. The restriction put on the coefficient is easily accepted by the data $(t=0.60)$.

coefficient for the capital stock in the employment equation of 0.74 implies moderate decreasing returns to scale. Surprisingly, I do not find a direct effect of contractual working time on employment. The coefficient for the capacity utilisation rate is highly significant. Finally, note that employment appears to adjust rather slowly to its optimal value.

Unemployment appears to have a significantly negative effect on wages. The size of the coefficient is close to the estimates in earlier studies (see van de Wijngaert, 1994, for a survey). The capital stock shows up to have a strong positive effect on wages. In the context of our model, this implies insider effects. In empirical research for the Netherlands, usually labour productivity is taken up in the wage equation instead of the capital stock. In the context of our further analysis, we prefer to take up the capital stock because labour productivity is partly endogenous in the model. Several wage pressure variables are significant and have the right sign. Particularly direct taxes on labour income appear to have strong effects on wages. Wages also increase in the generosity of unemployment benefits, although the effect is rather small. Contractual working time appears to be a major determinant of real hourly wages: a $1 \%$ decrease in working time implies an increase in hourly wage costs of $0.77 \%$. We did not discover any earlier empirical study on the relationship between hours and wages for the Netherlands. Our result is however consistent with theory and with the recent empirical findings for Germany by Hunt (1996).

The estimated long-run wage elasticity of labour supply of 0.28 is comparable with earlier studies on Dutch microdata (see Renaud \& Siegers, 1984). Unemployment appears to have a negative effect on labour-force participation, 
Table 2

The effect of exogenous variables on the unemployment rate and decomposition of changes in equilibrium unemployment

\begin{tabular}{|c|c|c|c|c|}
\hline & $\begin{array}{l}\text { Effect of a } 1 \% \\
\text { increase in } \\
\text { exogenous } \\
\text { variable }\end{array}$ & $\begin{array}{l}\text { Decomposition } \\
\text { unemployment } \\
\text { change } \\
1974-1981\end{array}$ & $\begin{array}{l}\text { Decomposition } \\
\text { unemployment } \\
\text { change } \\
1982-1989\end{array}$ & $\begin{array}{l}\text { Decomposition } \\
\text { unemployment } \\
\text { change } \\
1990-1994\end{array}$ \\
\hline Capital stock & 0.04 & -0.9 & -0.5 & -0.6 \\
\hline Demographic variables $^{\mathrm{a}}$ & 0.46 & +0.8 & +2.8 & +0.9 \\
\hline Capacity utilisation rate & 0.50 & -0.1 & +2.5 & +1.1 \\
\hline Contractual working time & 0.17 & -1.4 & -1.1 & -0.0 \\
\hline Tax wedge & 0.22 & +2.2 & -0.1 & -0.9 \\
\hline Consumer-producer prices & 0.09 & +1.1 & +0.2 & +0.4 \\
\hline Replacement rate & -0.02 & -0.2 & +0.1 & +0.2 \\
\hline $\begin{array}{l}\text { Total change according to } \\
\text { the model }\end{array}$ & & +1.5 & +3.9 & +1.1 \\
\hline $\begin{array}{l}\text { Actual change in } \\
\text { unemployment }\end{array}$ & & +2.2 & +4.3 & -0.1 \\
\hline
\end{tabular}

a Demographic variables include the change in working-age population corrected for the number of people living on early-retirement and disability benefits, and the change in the worker-labour year ratio (part-time work).

implying that the discouraged worker effect dominates the added worker effect, which is consistent with the findings by Van Mourik and Siegers (1991) for the Netherlands. Finally, the replacement rate turns out to affect labour-force participation negatively.

\section{Accounting for unemployment growth}

Solving the model for the unemployment rate and substituting in the estimated parameters reported in the previous section, we can explain changes in Dutch unemployment. We will focus on changes in equilibrium unemployment, i.e., after all adjustment processes have been worked through, conditional on the actual values of the capacity utilisation variable. The effect of exogenous variables on the unemployment rate, as well as the decomposition of changes in unemployment for the periods 1970-1977, 1978-1985, and 1986-1994 are reported in Table 2.

The estimated coefficients of the employment, wage and labour supply equations imply that the potential effect of exogenous shocks on unemployment is mitigated by more than $50 \%$ due to wage and labour supply adjustments. Population growth appears to push up unemployment strongly. This result confirms the findings by Kuipers and Kuper (1991) for the Netherlands, and by Madsen (1994) for the UK. It is however in strong contrast to the results obtained by Bean et al. (1986) and Lever (1991) for the 
Netherlands. In both studies labour-force growth is restricted to be neutral with respect to unemployment. Capital formation appears to have only a small effect on unemployment, due to the strong link between real hourly wages and the capital stock. This result puts some doubts on the validity of popular statements that we need investments to rise in order to lower unemployment. Apart from effects due to higher taxes and social premiums, rising benefit levels are not found to contribute to unemployment growth. The adverse effect on labour supply dominates the negative employment effects of the replacement rate. ${ }^{2}$ This result points to the importance of treating labour supply as an endogenous variable. Earlier studies in this field unanimously concluded that the replacement rate affects unemployment positively, even apart from effects due to higher taxes. Further, it appears that work sharing reduces unemployment, although only $17 \%$ of the potential one-to-one effect rests after all adjustment processes have been worked through. This is due to (1) the rise in hourly wages after working hours are reduced, and (2) wage and labour supply adjustments in response to unemployment changes. The result implies that total hours worked and production will be damaged quite strongly if working hours are reduced. Turning to the wage pressure variables, especially direct taxes appear to have strong effects on unemployment due to the large extent to which wage setters manage to shift this burden onto employers. The effect of the consumer-producer price gap appears to be smaller, which is a consequence of the relatively moderate impact of this variable on wages. Finally, the influence of capacity utilisation appears to be quite strong, leading to cyclical variation in unemployment.

The explanatory power of the model appears to be reasonably good. Population growth (corrected for the change in the number of people living on early retirement and disability benefits) appears to be a major cause of the long term upward trend in unemployment. Furthermore, it appears that reductions in contractual working hours have had considerable effects on unemployment, despite its strong adverse effect on employment measured in hours. Taxes pushed up unemployment during the 70s. The same is true for the gap between consumer and producer prices. The subsequent reductions in the tax wedge in the second half of the $80 \mathrm{~s}$ and the beginning of the 90 s reduced unemployment by about one percentage point. The aggregate demand variable is quite influential, leading to large short-term fluctuations in unemployment. This is especially the case in the beginning of the eighties. Capital formation has lowered unemployment, although the effect is rather small. Finally, apart from effects via the tax wedge, the replacement rate has virtually no effect on unemployment, for reasons already mentioned above.

\footnotetext{
${ }^{2}$ Note that while the adverse effect on labour supply weakens the total effect of the replacement rate on unemployment, it strengthens the positive effect of high benefits on total inactivity.
} 


\section{Conclusions}

In this paper, we have analysed the Dutch labour market by means of a small macroeconomic model, consisting of an employment equation, a real wage equation, and an equation for labour force participation. We have used the model to detect the causes of the rise in unemployment since the early $70 \mathrm{~s}$ in the Netherlands. Further empirical research could be directed at treating the capital stock as an endogenous variable. This might cast light on some further interrelations. Moreover, the analysis would benefit from having a more complete dataset, including data on institutional aspects like the level of competitiveness on product markets and the power of trade unions.

\section{Acknowledgments}

I am grateful to two anonymous referees, the Editor, D.P. Broer, J.C. Siebrand and O.H. Swank for useful comments on earlier drafts. Furthermore, the analysis benefited from discussions with many other colleagues. All views expressed and remaining errors are the author's own.

\section{References}

Bean, C. R. (1994). European unemployment: a survey. Journal of Economic Literature, 32, 573-619.

Bean, C. R., Layard, R., \& Nickell, S. J. (1986). The rise in unemployment: a multi-country study. Economica, 53 supplement, 1-22.

Calmfors, L. (1985). Work sharing, employment and wages. European Economic Review, 27, 293 -309. den Butter, F. A. G. (1993). De determinanten van de arbeidsvraag in Nederland. Maandschrift Economie, 57, 67-87.

Dur, R. A. J. (1996). Explaining unemployment trends in The Netherlands. Ocfeb Research Memorandum, 9609, Rotterdam.

Hunt, J. (1996). The response of wages and actual hours worked to the reductions of standard hours. NBER Working Paper 5716, Cambridge, MA, 1996.

Kuipers, S. K., \& Kuper, G. H. (1991). On the persistence of unemployment in the Netherlands: a simple theory and some evidence. In: C. de Neubourg (Ed.), The art of full employment: unemployment policy in open economies, pp. 105-127. Amsterdam: North-Holland.

Layard, R., \& Nickell, S. J. (1985). The causes of British unemployment. National Institute Economic Review, 111, 62-85.

Layard, R., \& Nickell, S. J. (1986). Unemployment in Britain. Economica, 53 supplement, 121-169.

Layard, R., Nickell, S., \& Jackman, R. (1991). Unemployment: macroeconomic performance and the labour market. Oxford: Oxford University Press.

Lever, M. H. C. (1991). Union wage setting and unemployment in the Netherlands (1965-1987). Applied Economics, 23, 1579-1585.

Madsen, J. B. (1994). The rise in UK unemployment: the search for an explanation. International Review of Applied Economics, 8, 251-265.

Pissarides, C. A. (1991). Real wages and unemployment in Australia. Economica 58, 35-55. 
Renaud, P. S. A., \& Siegers, J. J. (1984). Income and substitution effects in family labour supply. De Economist, 132, 350-366.

van de Wijngaert, R. (1994). Trade unions and collective bargaining in the Netherlands. Amsterdam: Thesis Publishers.

van Mourik, A., \& Siegers, J. J. (1991). Labour market conditions and labour force participation: the case of The Netherlands. Applied Economics, 23, 87-94. 